American Journal of Applied Sciences 8 (9): 854-859, 2011

ISSN 1546-9239

(C) 2011 Science Publications

\title{
Assessing Soil Biological Properties of Natural and Planted Forests in the Malaysian Tropical Lowland Dipterocarp Forest
}

\author{
${ }^{1}$ Daljit Singh Karam, ${ }^{1,2}$ Arifin Abdu, ${ }^{3,4}$ O. Radziah, ${ }^{3} \mathrm{~J}$. Shamshuddin, \\ ${ }^{1,2}$ Hazandy Abdul-Hamid, ${ }^{1}$ Nik M. Majid, ${ }^{1}$ Mohanaselvi Panicker \\ and ${ }^{5}$ Nor Halizah Abd. Halim \\ ${ }^{1}$ Department of Forest Production, Faculty of Forestry, \\ ${ }^{2}$ Laboratory of Sustainable Bioresource Management, \\ Institute of Tropical Forestry and Forest Products, \\ ${ }^{3}$ Department of Land Management, Faculty of Agriculture, \\ ${ }^{4}$ Laboratory of Food Crops and Floriculture, Institute of Tropical Agriculture, \\ University Putra Malaysia, 43400 UPM Serdang, Selangor \\ ${ }^{5}$ Forestry Department Peninsular Malaysia, 50660 Kuala Lumpur, Malaysia
}

\begin{abstract}
Problem statement: A study was conducted to evaluate and compare the soil biological properties of a natural forest and an 18-year-old stand of Shorea leprosula in Chikus Forest Reserve, Perak, Malaysia. Approach: Soils were sampled at depths of 0-15 cm (topsoil) and 15-30 cm (subsoil) in six subplots $(20 \times 20 \mathrm{~m})$ of natural forest $(\mathrm{C} 1)$ and of a planted S. leprosula (C2) plot. Fresh composite soil samples were kept in UV-sterilized polyethylene bags prior to analysis in the laboratory. The microbial population count was determined using a spread-plate count technique. The microbial enzymatic activity was elucidated using a Fluorescein Diacetate (FDA) hydrolysis assay; microbial biomass was extracted using a rapid chloroform fumigation extraction method. The Microbial Biomass C (MBC) was determined by wet dichromate oxidation; Kjeldahl digestion and a distillation method were used for evaluation of Microbial Biomass N (MBN). Results: Results indicate that only the microbial biomass $\mathrm{N}$ and the population count in the soil at the $0-15 \mathrm{~cm}$ depth were found to be higher in $\mathrm{C} 1$ compared to $\mathrm{C} 2$. The higher microbial population count in the soil at the $0-15 \mathrm{~cm}$ depth of $\mathrm{C} 1$ compared to $\mathrm{C} 2$ was enhanced by the large amount of organic matter that serves as a suitable medium for soil microbial growth. The higher $\mathrm{MBN}$ in the $\mathrm{C} 1$ soil was also influenced by the high content of organic material available that encourages activities of decomposing bacteria to take place. Similarities in the soil biological properties of the plots with regard to enzymatic activity and microbial biomass Care believed to be influenced by the same topographic gradient. The higher $\mathrm{MBC} / \mathrm{MBN}$ ratios found in soils of $\mathrm{C} 2$ compared to $\mathrm{C} 1$ were due to the low availability of $\mathrm{N}$ compared to $\mathrm{C}$, might result from $\mathrm{N}$ utilization by soil microbes for organic material decomposition. Conclusion: There are similarities in microbial enzymatic activity and biomass $\mathrm{C}$, but not in microbial population counts and biomass N, between a natural forest and an 18-year-old stand of S. leprosula in Chikus Forest Reserve, Perak, Malaysia.
\end{abstract}

Key words: Natural forest, planted forest, microbial population, enzymatic activity, biomass C and N, Fluorescein Diacetate (FDA), Forestry Department Peninsular Malaysia (FDPM), Soil analyses, soil fertility

\section{INTRODUCTION}

Forest rehabilitation is one of the vital strategies used to restore a degraded forest to its initial state (Singh et al., 2011; Arifin et al., 2008; Hamzah et al., 2009; Zaidey et al., 2010: Heryati et al., 2011a; 2011b). Rehabilitation also helps to reduce the demand for woody and non-woody products from natural forest. Therefore, it is crucial to carry out soil fertility evaluations of rehabilitated forests to evaluate the success of rehabilitation efforts.

It is undeniable that soil biological activity plays a key role in the catalyzing cycles of nutrients in the soil. Bollard and Stotzky (1990) found that the sensitive

Corresponding Author: Arifin Abdu, Department of Forest Production, Faculty of Forestry, University Putra Malaysia, 43400 UPM Serdang, Selangor, Malaysia Tel: +603-89467177 Fax: +603-89432514 
nature of microbial activity to environmental changes made it a good indicator of soil fertility. Islam and Weil (2000) also justified the importance of including soil biological parameters in determining soil fertility; these parameters can show how land management affects soil microbial biomass. In addition, Van Dobben and McConnell (1975) found that $90 \%$ of the energy cycle in the soil was induced by microbial decomposition activity, which provided a preview of soil organic matter turnover in a particular area.

The Chikus Forest Reserve, Perak, Malaysia is considered to be a lowland dipterocarp forest and it was subjected to a forest rehabilitation program by the Forestry Department of Peninsular Malaysia (FDPM) and the Japan International Cooperation Agency (JICA) via the Multi-Storied Forest Management System (MSFMS) (Arifin et al., 2008). Many soil fertility evaluations were carried out, focusing on the physicochemical and mineralogical properties of the soil in these forests (Arifin et al., 2008; Abdu et al., 2007; Saga et al., 2010); however, no information on the soil biological properties was collected. Hence, this study was carried out to evaluate and compare the soil biological properties of natural and rehabilitated forests.

\section{MATERIALS AND METHODS}

Study site and soil sampling: The study was carried out in a natural forest $\left(\mathrm{N} 04.10076^{\circ} \mathrm{E} 101.19411^{\circ}, \pm 28\right.$ $\mathrm{m})$ and an 18-year-old stand of Shorea leprosula (N $04.09197^{\circ}$ E $101.19499^{\circ}, \pm 28 \mathrm{~m}$ ) in January, 2011. The area has an average annual precipitation of 3223 $\mathrm{mm}$ and a mean temperature of $27.7^{\circ} \mathrm{C}$. S. leprosula was planted in 1992 through collaborative work of the Multi-Storied Forest Management System involving the Forestry Department Peninsular Malaysia, the Perak State Forestry Department and the Japan International Cooperation Agency (JICA). The planting distance was $10 \mathrm{~m} \times 3 \mathrm{~m}$. Natural forest and planted S. leprosula plots were marked as $\mathrm{C} 1$ and $\mathrm{C} 2$, respectively. Six subplots were established at each plot and a composite sample was randomly collected from depths of $0-15 \mathrm{~cm}$ (topsoil) and 15-30 cm (subsoil). The fresh composite soil samples were kept in UV-sterilized polyethylene bags under $0-4^{\circ} \mathrm{C}$ in ice-filled polystyrene boxes prior to analysis.

Soil analyses: The spread-plate technique described by Sleytr et al. (2007) was used for microbial population counts. The microbial enzymatic activity was evaluated using the Fluorescein Diacetate (FDA) hydrolysis assay (Sanchez-Monedero et al., 2008). Microbial biomass was extracted via a rapid ethanol-free chloroform fumigation extraction technique (Witt et al., 2000).
Microbial Biomass C (MBC) was analysed by wet dichromate oxidation (Vasquez-Murrieta et al., 2007; Vance et al., 1987) and microbial biomass $\mathrm{N}$ (MBN) was elucidated through Kjeldahl digestion and a distillation technique (Simmone et al., 1997; Brookes et al., 1985). The loss-on-ignition method used in Ahmadpour et al. (2010) was used for soil organic matter and organic carbon determination. Kjeldahl digestion was used for total $\mathrm{N}$ evaluation and soil acidity was determined using a glass electrode and a soil: water suspension ratio of 1:2.5 (Akbar et al., 2010).

Data analyses: Mean values were compared using the Student's t-test. Linear regression analysis using SPSS ver. 16.0 was performed to determine any correlations or relationships derived from comparisons between microbial biomass $\mathrm{C}$ and organic matter and between microbial biomass $\mathrm{N}$ and total $\mathrm{N}$ at the same soil depths.

\section{RESULTS}

Microbial population: Microbial population counts were significantly higher $(\mathrm{P} \leq 0.05)$ in the soil of $\mathrm{C} 1$ $\left(3.45 \pm 0.12 \log _{10} \mathrm{~g}^{-1}\right.$ soil) compared to C2 (2.90 \pm 0.06 $\log _{10} \mathrm{~g}^{-1}$ soil) at the $0-15 \mathrm{~cm}$ depth; no significant differences $(\mathrm{P} \leq 0.05)$ were detected in the soils at the $15-30 \mathrm{~cm}$ depth for either plot (Fig. 1). Microbial population counts in the soils at the $15-30 \mathrm{~cm}$ depth for $\mathrm{C} 1$ and $\mathrm{C} 2$ were $3.13 \pm 0.13 \log _{10} \mathrm{~g}^{-1}$ soil and $2.75 \pm$ $0.16 \log _{10} \mathrm{~g}^{-1}$ soil, respectively.

Microbial enzymatic activity: The $\mathrm{C} 1$ and $\mathrm{C} 2$ plots exhibited no significant differences $(\mathrm{P} \leq 0.05)$ in microbial enzymatic activity at the same soil depths (Fig. 2). Means of microbial enzymatic activity for $\mathrm{C} 1$ at the $0-15 \mathrm{~cm}$ and $15-30 \mathrm{~cm}$ soil depths were $26.51 \pm$ $0.63 \mu \mathrm{g} \mathrm{g}^{-1}$ soil $0.5 \mathrm{~h}^{-1}$ and $25.74 \pm 1.13 \mu \mathrm{g} \mathrm{g}^{-1}$ soil $0.5 \mathrm{~h}^{-}$ ${ }^{1}$, respectively; for $\mathrm{C} 2$, the means were $24.89 \pm 1.22 \mu \mathrm{g}$ $\mathrm{g}^{-1}$ soil $0.5 \mathrm{~h}^{-1}$ and $22.92 \pm 0.76 \mu \mathrm{g} \mathrm{g}^{-1}$ soil $0.5 \mathrm{~h}^{-1}$, respectively.

MBC: No significant differences in soil $\mathrm{MBC}(\mathrm{P} \leq 0.05)$ were found between $\mathrm{C} 1$ and $\mathrm{C} 2$ at the same soil depths (Fig. 3). Means of $\mathrm{MBC}$ for $\mathrm{C} 1$ and $\mathrm{C} 2$ at the $0-15 \mathrm{~cm}$ soil depth were $824 \pm 34 \mu \mathrm{g} \mathrm{g}^{-1}$ soil and $542 \pm 329 \mu \mathrm{g} \mathrm{g}$ ${ }^{1}$ soil, respectively. The means of $\mathrm{MBC}$ for $\mathrm{C} 1$ and $\mathrm{C} 2$ at the $15-30 \mathrm{~cm}$ soil depth were $524 \pm 115 \mu \mathrm{g} \mathrm{g}^{-1}$ soil and $337 \pm 233 \mu \mathrm{g} \mathrm{g}^{1}$ soil, respectively.

MBN: The MBN was higher $(\mathrm{P} \leq 0.05)$ in $\mathrm{C} 1$ compared to $\mathrm{C} 2$ at both soil depths (Fig. 4). In C1, the means of the MBN were $149 \pm 20 \mu \mathrm{g} \mathrm{g}^{-1}$ soil at the $0-15 \mathrm{~cm}$ soil depth and $113 \pm 29 \mu \mathrm{g} \mathrm{g}^{-1}$ soil at the $15-30 \mathrm{~cm}$ soil depth. In contrast, the means of MBN in C2 were $37 \pm$ $4 \mu \mathrm{g} \mathrm{g}^{-1}$ soil and $9 \pm 4 \mu \mathrm{g} \mathrm{g}^{-1}$ soil at the 0 - 15 cmand 15 $30 \mathrm{~cm}$ depths, respectively. 
Am. J. Applied Sci., 8 (9): 854-859, 2011

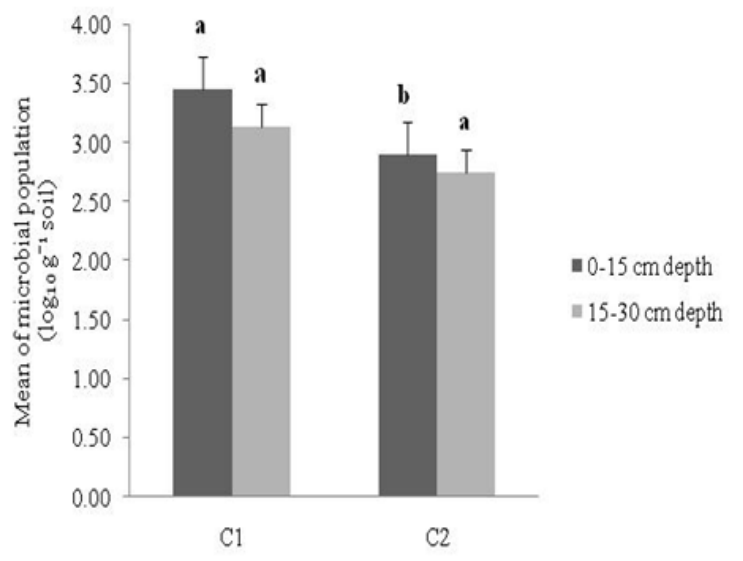

Fig. 1: Total means of soil microbial populations in the natural forest $(\mathrm{C} 1)$ and $S$. leprosula $(\mathrm{C} 2)$ plots. The different letters indicate significant differences between the means of the same soil depths in the natural forest (C1) and S. leprosula (C2) plots using the Student's t-test $(\mathrm{P} \leq 0.05)$

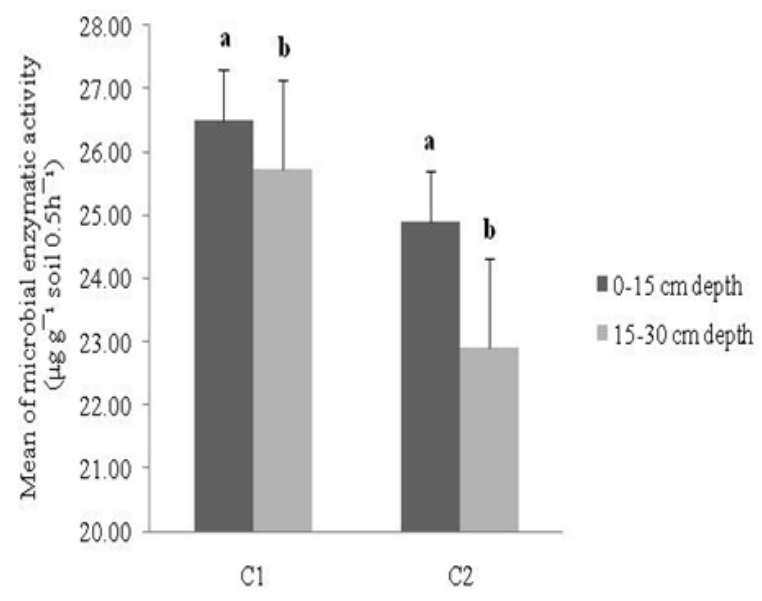

Fig. 2: Total means of soil microbial enzymatic activity in the natural forest $(\mathrm{C} 1)$ and $S$. leprosula $(\mathrm{C} 2)$ plots. The different letters indicate significant differences between means of the same soil depths in the natural forest (C1) and S. leprosula (C2) plots using the Student's t-test $(\mathrm{P} \leq 0.05)$

Microbial biomass $\mathrm{C}$ to microbial biomass $\mathrm{N}$ (MBC/MBN) ratio: The ratio of $\mathrm{MBC} / \mathrm{MBN}$ was found to be higher in $\mathrm{C} 2$ compared to $\mathrm{C} 1$ (Fig. 5). The $\mathrm{MBC} / \mathrm{MBN}$ ratio for $\mathrm{C} 1$ was $6.35 \pm 1.38$ and $6.39 \pm$ 2.46 at the $0-15 \mathrm{~cm}$ and $15-30 \mathrm{~cm}$ soil depths, respectively. On the other hand, the $\mathrm{MBC} / \mathrm{MBN}$ ratio for $\mathrm{C} 2$ at the $0-15 \mathrm{~cm}$ and $15-30 \mathrm{~cm}$ soil depths were $16.79 \pm 9.72$ and $37.84 \pm 22.36$, respectively.

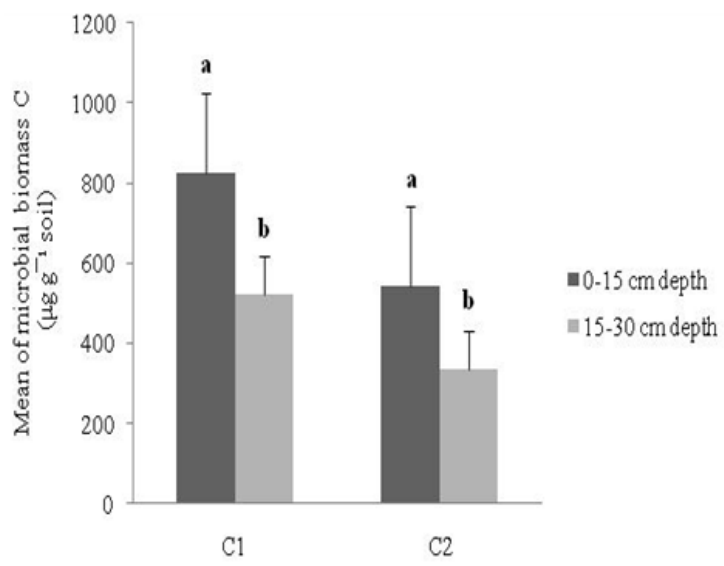

Fig. 3: Total means of soil Microbial Biomass C (MBC) in the natural forest (C1) and S. leprosula (C2) plots. The different letters indicate significant differences between means of the same soil depths in the natural forest (C1) and S. leprosula (C2) plots using the Student's t-test $(\mathrm{P} \leq 0.05)$

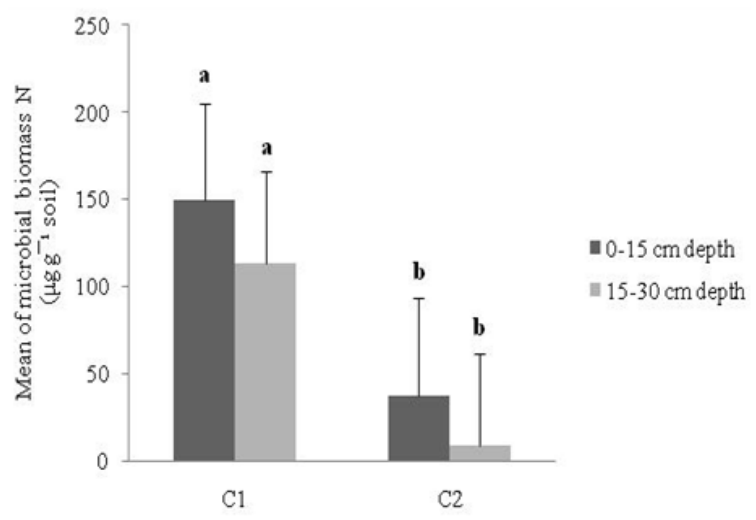

Fig. 4:Total means of soil Microbial Biomass N (MBN) in the natural forest $(\mathrm{C} 1)$ and $S$. leprosula $(\mathrm{C} 2)$ plots. The different letters indicate significant difference between means of the same soil depths at the natural forest (C1) and S. leprosula (C2) plots using the Student's t-test $(\mathrm{P} \leq 0.05)$

Organic matter, organic $\mathrm{C}$, total $\mathrm{N}$ and soil acidity: The soil organic matter and organic $\mathrm{C}$ were significantly higher $(\mathrm{P} \leq 0.05)$ in $\mathrm{C} 1$ compared to $\mathrm{C} 2$ at the same soil depth (Table 1). In addition, total $\mathrm{N}$ was also found to be significantly different $(\mathrm{P} \leq 0.05)$, except at the $15-30 \mathrm{~cm}$ soil depth. No significant difference was found in soil acidity at the $0-15 \mathrm{~cm}$ soil depth, but the soil of $\mathrm{C} 2$ was significantly more acidic $(\mathrm{P} \leq 0.05)$ at the $15-30 \mathrm{~cm}$ soil depth than the soil of $\mathrm{C} 1$. 
Am. J. Applied Sci., 8 (9): 854-859, 2011

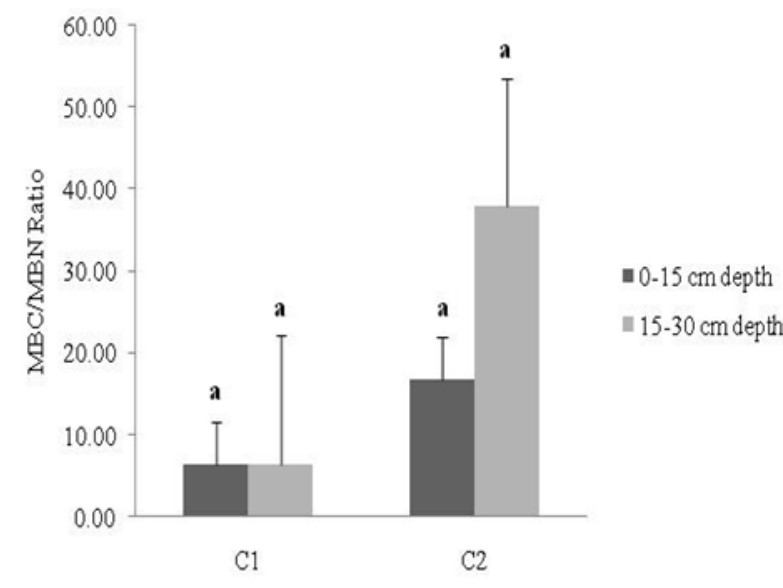

Fig. 5:Ratios of soil microbial biomass $\mathrm{C}$ to microbial biomass $\mathrm{N}(\mathrm{MBC} / \mathrm{MBN})$ in the natural forest (C1) and S. leprosula(C2) plots. The different letters indicate significant difference between means of the same soil depths at the natural forest (C1) and $S$. leprosula (C2) plots using the Student's t-test $(\mathrm{P} \leq 0.05)$

Table 1:Selected soil physico-chemical properties of the natural forest (C1) and S. leprosula (C2) plots

\begin{tabular}{lll}
\hline & $0-15 \mathrm{~cm}$ & $15-30 \mathrm{~cm}$ \\
\hline & Organic matter (\%) \\
$\mathrm{C} 1$ & $12.31 \pm 1.47 \mathrm{a}$ & \\
$\mathrm{C} 2$ & $8.52 \pm 0.55 \mathrm{~b}$ & $9.63 \pm 1.62 \mathrm{a}$ \\
& Organic C (\%) & $8.07 \pm 0.45 \mathrm{~b}$ \\
$\mathrm{C} 1$ & $7.14 \pm 0.85 \mathrm{a}$ & \\
$\mathrm{C} 2$ & $4.94 \pm 0.32 \mathrm{~b}$ & $5.58 \pm 0.94 \mathrm{a}$ \\
& Total N (\%) & $4.68 \pm 0.26 \mathrm{~b}$ \\
$\mathrm{C} 1$ & $1.66 \pm 0.20 \mathrm{a}$ & $1.26 \pm 0.25 \mathrm{c}$ \\
$\mathrm{C} 2$ & $1.10 \pm 0.15 \mathrm{~b}$ & $0.87 \pm 0.06 \mathrm{c}$ \\
& pH- $\mathrm{H}_{2} \mathrm{O}$ & \\
$\mathrm{C} 1$ & $4.16 \pm 0.08 \mathrm{a}$ & $4.65 \pm 0.10 \mathrm{a}$ \\
$\mathrm{C} 2$ & $4.22 \pm 0.03 \mathrm{a}$ & $4.30 \pm 0.04 \mathrm{~b}$ \\
\hline Note: & The different letters within columns indicate significant
\end{tabular}

Note: The different letters within columns indicate significant differencesbetween means of the same soil depths at the natural forest (C1) and S. leprosula (C2) plots using the Student's t-test $(\mathrm{P} \leq 0.05)$

No linear relationships were found between microbial biomass $\mathrm{C}$ and organic matter or between microbial biomass $\mathrm{N}$ and total $\mathrm{N}$ in the soils of $\mathrm{C} 1$ and $\mathrm{C} 2$ at either soil depth.

\section{DISCUSSION}

Higher microbial population counts in soil of natural forest compared to the $S$. leprosula plot could be due to the high content of organic matter and humic substances in the soil at the $0-15 \mathrm{~cm}$ depth. The high content of organic material in the soil would trigger soil microbial activities and, thus, could subsequently result in a larger population in the $\mathrm{C} 1$ soil.
The similarities between the plots in soil microbial enzymatic activity and MBC could be due to the fact these plots are located at the same elevation; both plots were located about $28 \mathrm{~m}$ above sea level, which is considered to be lowland forest area. Furthermore, both areas are classified as tropical rainforest and receive heavy rainfall; hence, these factors promote the same range of microbial diversity and activity (Barbhuiya et al., 2004). Arunachalam and Pandey (2003) found that soil microbial biomass could be a more reliable indicator of ecosystem recovery than other ecological approaches because it is the most labile and sensitive portion of organic matter and determines soil fertility.

Arifin et al. (2008) and Carter (2002) reported that the distribution of soil organic biodiversity is also influenced by the type and carrying capacity of soil, the weather and how the land at a particular site was managed. The soil MBN was found to be significantly different between the plots for both soil depths. This is could be due to low availability of total $\mathrm{N}$ in the $S$. leprosula plot. In the field, the natural forest area was waterlogged, whereas the $S$. leprosula plot was welldrained. In the natural forest, adequate supply of water or suitable humidity leads to enhanced growth of nitrogen-fixing bacteria and allows increases in the decomposition of biomass $\mathrm{N}$ to take place. In addition, Behera and Sahani (2003) found that optimum microbial activity occurs when there is an adequate supply of growth substrates. Hence, drought or inadequate supply of water itself will inhibit or slow down nutrient cycling and the decomposition of organisms by affecting the microbial activity in the soil. However, the lower level of MBN compared to MBC in both plots could be due to the loss of MBN from the ecosystem that is caused by low $\mathrm{N}$ mobilization (Maithani et al., 1998).

Differences in the $\mathrm{MBC} / \mathrm{MBN}$ ratio between the natural forest and $S$. leprosula plots indicate that qualitative changes take place in microbial biomass; these changes are believed to be enhanced by the cycling and turnover processes of micro flora in soils (Behera and Sahani, 2003). The MBC/MBN ratios found at the $0-15 \mathrm{~cm}$ and $15-30 \mathrm{~cm}$ depths in the natural forest were within the optimal range of 5-8 (Joergensen et al., 1995). However, the higher MBC/MBN ratio in the $S$. leprosula plot compared to the natural forest could be due to a higher ratio in the $\mathrm{C} 2$ soil of fungi to bacteria or actinomycetes (Behera and Sahani, 2003; Campbell et al., 1994). Furthermore, fungal domination of microbial biomass also contributes to the higher $\mathrm{MBC} / \mathrm{MBN}$ ratio we observed in soil of the S. leprosula plot; the higher MBC/MBN ratio in the lower soil layer of both the natural forest and S. leprosula plots 
indicates a low level of accumulation of organic matter and fine roots (Bremer and Van Kessel, 1992; Maithani et al., 1996). The higher MBC/MBN ratio in soil of the $S$. leprosula plot could be caused by the higher organic matter and organic $\mathrm{C}$ content compared to the availability of total $\mathrm{N}$ in the soil at natural forest. The low N in the soil of the S. leprosula plot also could be due to the available $\mathrm{N}$ being utilized by microbes during the decomposition of soil organic matter or humus. This result indicates that reforestation of a particular site requires more time to populate adequate detrital medium for microbial growth (Arunachalam and Pandey, 2003).

The dynamics of soil biological properties provide us with data regarding the current conditions and early effects of land management, monitoring and sustainability status in a particular area. Furthermore, the abundance of microbial communities, which catalyze numerous enzymatic cycles of nutrients in the soil, will subsequently increase and maintain the soil fertility and productivity (Behera and Sahani, 2003).

\section{CONCLUSION}

Analysis of the biological activities of the soils in a natural forest and the $S$. leprosula plantation in Chikus Forest Reserve, Perak showed no significant differences, with the exceptions of microbial biomass $\mathrm{N}$ and the microbial population counts at the $0-15 \mathrm{~cm}$ soil depth. Hence, the data prove that rehabilitation of degraded forestland helps restore soil biological activities to their original state or to the extent seen in natural forests.

\section{ACKNOWLEDGEMENT}

We wish to thank the Perak South District, Department of Forestry, Perak who allowed us to carry out the research project. This study was financially supported by the Fundamental Research Grant Scheme (FRGS) from the Ministry of Higher Education of Malaysia (MOHE) through the Universiti Putra Malaysia (UPM), Malaysia. We would also like to express our gratitude to all of the Department of Forestry staff in Perak who helped us with the fieldwork.

\section{REFERENCES}

Ahmadpour, P., A.M. Nawi, A. Abdu, H. Abdul-Hamid and D.K. Singh et al., 2010. Uptake of heavy metals by Jatropha curcas L. planted in soils containing sewage sludge. Am. J. Applied Sci., 7: 1291-1299. DOI: 10.3844/ajassp.2010.1291.1299
Akbar, M.H., O.H., Ahmed, A.S. Jamaluddin, N.M.N.A. Majid and H. Abdul-Hamid et al., 2010. Differences in soil physical and chemical properties of rehabilitated and secondary forests. Am. J. Applied Sci., 7: 1200-1209. DOI:10.3844/ajassp.2010.1200.1209

Arifin, A., S. Tanaka, S. Jusop, N.M. Majid and Z. Ibrahim et al., 2008. Assessment on soil fertility status and growth performance of planted dipterocarp species in Perak, Peninsular Malaysia. J. Applied Sci., 8: 3795-3805. DOI: 10.3923/jas.2008.3795.3805

Arunachalam, A. and H.N. Pandey, 2003. Ecosystem restoration of jhum fallows in northeast India: microbial $\mathrm{C}$ and $\mathrm{N}$ along altitudinal and successional gradients. Restor. Ecol., 11: 168-173. DOI: 10.1046/j.1526-100X.2003.00013.x

Barbhuiya, A.R., A. Arunachalam, H.N. Pandey, K. Arunachalam and M.L. Khan et al., 2004. Dynamics of soil microbial biomass $\mathrm{C}, \mathrm{N}$ and $\mathrm{P}$ in disturbed and undisturbed stands of a tropical wetevergreen forest. Eur. J. Soil Biol., 40: 113-121. DOI: 10.1016/j.ejsobi.2005.02.003

Behera, N. and U. Sahani, 2003. Soil microbial biomass and activity in response to Eucalyptus plantation and natural regeneration on tropical soil. Forest Ecol. Manage., 174: 1-11. DOI: 10.1016/S03781127(02)00057-9

Bollard, J.M. and G. Stotzky, 1990. Soil Biochemistry. 1st Edn., Marcell Dekker, New York, ISBN-10: 0824782321, pp: 584.

Bremer, E. and C Van Kessel, 1992. Seasonal microbial biomass dynamics after addition of lentil and wheat residues. Soil Sci. Soc. Am. J., 56: 1141-1146.

Brookes, P.C., A. Landman, G. Pruden and D.S. Jenkinson, 1985. Chloroform fumigation and the release of soil nitrogen: A rapid direct extraction method to measure microbial biomass nitrogen in soil. Soil Biol. Biochem., 17: 837-842. DOI: 10.1016/0038-0717(85)90144-0

Campbell, B.M., P. Frost, J.A. King, M. Mawanza and L. Mhlanga, 1994. The influence of trees on soil fertility on two contrasting semi-arid soil types at Matopos, Zimbabwe. Agrofor. Syst., 28: 159-172. DOI: $10.1007 / \mathrm{BF} 00704827$

Carter, M.R., 2002. Soil quality for sustainable land management: Organic matter and aggregation interactions that maintain soil functions. Agron. J., 94: 38-47.

Hamzah, M.Z., A. Arifin, A.K. Zaidey, A.N. Azirim and I. Zahari et al., 2009. Characterizing soil nutrient status and growth performance of planted dipterocap and non-dipterocarp species on degraded forest land in Peninsular Malaysia. J. Applied Sci., 9: 4215-4223. DOI: 10.3923/ajas.2009.4215.4223 
Heryati, Y., A. Arifin, M.N. Mahat, H.A. Abdul-Hamid and S. Jusop et al., 2011b. Comparing the fertility of soils under Khaya ivorensis plantation and regenerated degraded secondary forests. Am. J. Applied Sci., 8: 472-480. DOI: 10.3844/ajabssp.2011.472.480

Heryati, Y., D. Belawan, A. Abdu, M.N. Mahat and H. Abdul-Hamid et al., 2011a. Growth performance and biomass accumulation of a Khaya ivorensis plantation in three soil series of ultisols. Am. J. Agric. Biol. Sci., 6: 33-44. DOI: 10.3844/ajabssp.2011.33.44

Islam, K.R. and R.R. Weil, 2000. Land use effects on soil quality in a tropical forest ecosystem of Bangladesh. Agric. Ecosyst. Environ., 79: 9-16. DOI: 10.1016/S0167-8809(99)00145-0

Joergensen, R.G., T.H. Anderson, V. Wolters, 1995. Carbon and nitrogen relationships in the microbial biomass of soils in beech (Fagus sylvatica L.) forests. Biol. Fertil. Soils, 19: 141-147. DOI: 10.1007/BF00336150

Maithani, K., A. Arunachalam, R.S. Tripathi and H.N. Pandey, 1998. Nitrogen mineralization as influenced by climate, soil and vegetation in a subtropical humid forest in northeast India. Forest Ecol. Manage., 109: 91-101. DOI: 10.1016/S03781127(98)00246-1

Maithani, K., R.S. Tripathi, A. Arunachalam and H.N. Pandey, 1996. Seasonal dynamics of microbial biomass $\mathrm{C}, \mathrm{N}$ and $\mathrm{P}$ during regrowth of a disturbed subtropical humid forest in North-East India. Applied Soil Ecol., 4: 31-37. DOI: 10.1016/09291393(96)00101-1

Saga, B.T., O.H., Ahmed, A.S. Jamaluddin, H. AbdulHamid and S. Jusop et al., 2010. Selected soil morphological, mineralogical and sesquioxide properties of rehabilitated and secondary forests. Am. J. Environ. Sci., 6: 389-394. DOI: 10.3844/ajessp.2010.389.394

Sanchez-Monedero, M.A., C. Mondini, M.L. Cayuela, A. Roig and M. Contin et al., 2008. Fluorescein diacetate hydrolysis, respiration and microbial biomass in freshly amended soils. Biol. Fertil. Soils, 44: 885-890. DOI: 10.1007/s00374-0070263-1
Simmone, A.H., E.H. Simmone, R.R. Eitenmiller, H.A. Mills and C.P. Cresman III, 1997. Could the Dumas method replace the Kjeldahl digestion for nitrogen and crude protein determinations in foods? J. Sci. Food Agric., 73: 39-45. DOI: 10.1002/(SICI)1097-0010(199701)73:1<39::AIDJSFA717>3.0.CO;2-4

Singh, D.K., F. Abood, H. Abdul-Hamid, Z. Ashaari and A. Abdu, 2011. Boric acid toxicity trials on the wood borer Heterobostrychus aequalis Waterhouse (Coleoptera: Bostrychidae). Am. J. Agric. Biol. Sci., 6: 84-91. DOI: 10.3844/ajabssp.2011.84.91

Sleytr, K., A. Tietz, G. Langergraber and R. Haberl, 2007. Investigation of bacterial removal during the filtration process in constructed wetlands. Sci. Total Environ., 380: 173-180. DOI: 10.1016/j.scitotenv.2007.03.001

Van Dobben, W.H. and R. McConnell, 1975. Unifying Concepts in Ecology. 1st Edn., W. Junk, The Hague, ISBN9022005240, pp: 302.

Vance, E.D., P.C. Brookes and D.S. Jenkinson, 1987. An extraction method for measuring soil microbial biomass C. Soil. Biol. Biochem., 19: 703-707. DOI: 10.1016/0038-0717(87)90052-6

Vasquez-Murrieta, M.S., B. Govarts and L. Dendooven, 2007. Microbial biomass C measurements in soil of the central highlands of Mexico. Applied Soil Ecol., 35: 432-440. DOI: 10.1016/J.APSOIL.2006.06.005

Witt, C., J.L. Gaunt, C.C. Galicia, J.C.G. Ottow and H.U. Neue, 2000. A rapid chloroform-fumigation extraction method for measuring soil microbial biomass carbon and nitrogen in flooded rice soils. Biol. Fertil. Soils, 30: 510-519. DOI: 10.1007/s003740050030

Zaidey, A.K., A. Arifin, I. Zahari, A.H. Hazandy and M.H. Zaki et al., 2010. Characterizing soil properties of lowland and hill dipterocarp forests at Peninsular Malaysia. Int. J. Soil Sci., 5: 112-130. DOI: $10.3923 /$ ijss.2010.112.130 